\title{
The Response of Sorghum, Groundnut, Sesame, and Cowpea to Seed Priming and Fertilizer Micro-Dosing in South Kordofan State, Sudan
}

\section{Elgailani A. Abdalla ${ }^{1}$, Abdelrahman K. Osman ${ }^{1}$, Mahmoud A. Maki ${ }^{1}$, Fadlalmaola M. Nur ${ }^{1}$, Salah B. Ali ${ }^{1}$ and Jens B. Aune ${ }^{2, *}$}

1 Elobeid Research Station, Elobeid 611, Sudan; E-Mails: elgailani_ers@hotmail.com (E.A.A.); arkosman@hotmail.com (A.K.O.); mahmekki@yahoo.com (M.A.M.), fadelmoh75@yahoo.com (F.M.N.); salahbakor328@yahoo.com (S.B.A.)

2 Department of International Environment and Development Studies, Noragric, Norwegian University of Life Sciences (NMBU) P.O. Box 5003, N-1432 Ås, Norway

* Author to whom correspondence should be addressed; E-Mail: jens.aune@nmbu.no; Tel.: +47-9768-1283.

Academic Editor: Yantai Gan

Received: 8 July 2015 / Accepted: 18 September 2015 / Published: 29 September 2015

\begin{abstract}
This study was undertaken with the objective of evaluating micro-dosing of mineral fertilizer combined with seed priming in sorghum, groundnut, sesame, and cowpea. On-station and on-farm trials were conducted for two consecutive seasons

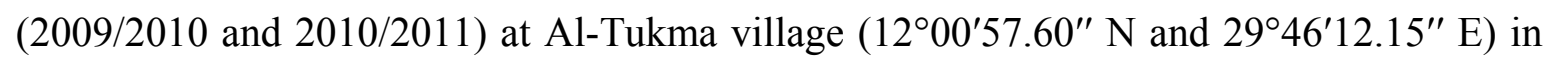
South Kordofan State, $15 \mathrm{~km}$ southeast of Dilling city. Heavy cracking clay soil is the dominant soil type in the region with low fertility. The experiments for each crop consisted of two priming levels (primed seeds vs. non-primed) and four micro-doses of NPK mineral fertilizer $(0,0.3,0.6$ and 0.9 g per planting pocket or hole). On-farm trials in 15 fields consisted of control, seed priming, and seed priming + micro fertilizer $(0.3 \mathrm{~g} / \mathrm{planting}$ hole). Data collected included plant vigor, stand count, plant height, grain and straw yield, seed weight, and other relevant agronomic traits. This study shows that it is possible to increase productivity of sorghum, sesame, groundnut, and cowpea in the semi-arid cracking clay of South Kordofan State at a low cost and with a moderate risk for farmers through seed priming and micro-dosing of fertilizers. Seed priming combined with micro-dosing NPK mineral fertilizer of $0.9 \mathrm{~g}$ was the best treatment for plant establishment, seedling vigor, grain yield, and hay yield in sorghum and groundnut,
\end{abstract}


whereas the combination of seed priming and $0.3 \mathrm{~g}$ micro-doing of fertilizer was the best in sesame. Seed priming and micro-dosing of fertilizer of $0.6 \mathrm{~g}$ was the best combination for cowpea. On-farm trial results indicated that priming alone and priming combined with fertilizer application significantly increased the yields of sorghum, groundnut, and cowpea over the control $(P=0.01)$. Of the crops tested, groundnut responded most favorably to micro-dosing and seed priming, with a value to cost ratio (VCR) of 26.6, while the highest VCR for sorghum, sesame, and cowpea was 12.5, 8.0 and 4.4, respectively. For the best productivity and profitability, we recommend using seed priming in combination with the micro-dosing of $0.9 \mathrm{~g} /$ hole of 15:15:15 NPK fertilizer for sorghum and groundnut, of 0.3 $\mathrm{g} /$ hole for sesame, and of $0.6 \mathrm{~g} /$ hole for cowpea grown in the semiarid South Kordofan State of Sudan.

Keywords: seed treatment; fertilization; yield; gross margin; on-farm; intensificaton

\section{Introduction}

Traditional dry-land farming is the major production system and source of livelihood for more than $75 \%$ of the population in Western Sudan. The major food crops grown are millet and sorghum while groundnut and sesame are the major cash crops. Other crops grown are cowpea, maize, cotton, and okra. The productivity of the main crops are very low compared to other parts of the world [1]. This is due to a magnitude of natural and socio-economic constraints. Poor crop establishment and low soil fertility are particularly constraining for crop productivity.

The study site, South Kordofan State, falls in the semi-arid zone where heavy cracking clays constitute the dominant soil type. The region is characterized by seasonal variation in rainfall and low soil fertility. The maintenance of soil fertility is becoming one of the most important interventions required to increase crop productivity in the dry areas. Application of small amounts of mineral fertilizer in the planting hole is a more efficient way to apply mineral fertilizer compared to broadcasting. This method increases both yield and the efficiency of fertilizer application [2-6]. Another low-cost approach to increase yield under marginal dry land conditions is seed priming, a process of soaking seeds in water for a specific period prior to sowing [5,7,8]. Seed priming and fertilizer micro-dosing are recommended in the sandy soils of North Kordofan State as these methods have significantly improved crop establishment and increased the yield of rain-fed sorghum, pearl millet, groundnut, sesame, and cowpea $[6,9,10]$. The objective of the study was to evaluate the effect of placing small amounts of mineral fertilizer in the planting hole (micro-dosing) in combination with seed priming for sorghum, groundnut, sesame, and cowpea in South Kordofan State in Western Sudan, a location with heavy cracking clay soil and higher rainfall, compared to North Kordofan. 


\section{Materials and Methods}

Four field experiments were conducted for two consecutive seasons (2009/2010 and 2010/2011) at Al-Tukma village in South Kordofan State $\left(29^{\circ} 46^{\prime} 12.15^{\prime \prime} \mathrm{E}\right.$ and $\left.12^{\circ} 00^{\prime} 57.60^{\prime \prime} \mathrm{N}\right), 15 \mathrm{~km}$ southeast of Dilling city and $145 \mathrm{~km}$ north of Kadugli, the capital city of the state. This area is part of the central clay plain, where soils are dark, heavy cracking (vertisol), with high water-holding capacity and low nitrogen and phosphorus content.

Soil cores were taken to the depth of $0-10 \mathrm{~cm}$ prior to planting. The soil analysis showed a clay fraction of $74 \%$, very low nitrogen content $(0.02 \mathrm{ppm})$, moderate phosphorus content (30 ppm) and low potassium content $(0.78 \mathrm{ppm})$. NPK mineral fertilizer $(15: 15: 15)$ was used to compensate for low contents of the soil NPK.

The experiments were carried out under rain-fed conditions on sorghum (Sorghum bicolor (L.) Moench), groundnut (Arachis hypogea L.), sesame (Sesamum indicum L.), and cowpea (Vigna unguiculata (L.) WLAP). The experiments consisted two levels of priming (primed seeds vs. non-primed) and four levels of micro-dose of NPK $(15: 15: 15)$ mineral fertilizer $(0,0.3,0.6$ and 0.9 grams per planting pocket or hole $)$ giving eight $(2 \times 4$ factorial $)$ treatment combinations. The treatments were laid out in a randomized complete block design (RCBD) with four replications. The experimental plots were five meters long and three meters wide with $60 \mathrm{~cm}$ between-row spacing and between-plant spacing of 40, 20, 40 and $30 \mathrm{~cm}$ for sorghum, groundnut, sesame, and cowpea, respectively. Total annual rainfall at the nearest main meteorological station at Dilling was $675 \mathrm{~mm}$ and $562 \mathrm{~mm}$ during 2009/2010 and 2010/2011 seasons, respectively. The varieties used were Yarwasha, Gubeish, Obeid-1, and Ainelgazal of sorghum, groundnut, sesame, and cowpea, respectively. The fertilizer type was NPK (15-15-15) (Yara). Seeds of the four crops were soaked in water for eight hours (overnight) and then surface-dried for less than an hour for planting the next day. Before sowing, the seeds were treated with Apron Star (20\% Metalaxyl-m, 20\% Thiamethoxam and 2\% Difenoconazole) at a dose of $3 \mathrm{~g} / \mathrm{kg}$ seed. Two seeds per hole were planted for groundnut and cowpea, while 4-5 seeds were planted for sorghum and sesame, then thinned to 2-3 plants per hole two weeks after planting. The planting hole was opened using a traditional hoe and the seed and fertilizer were placed together in the planting pit at a depth of 5 to $7 \mathrm{~cm}$. The microdosing rates applied were $0.3,0.6$ and $0.9 \mathrm{~g}$ per pocket which corresponded to 6-7, 12-14, and 18-21 fertilizer granules per pocket, respectively.

The amount of fertilizer utilized per hectare for each crop differed according to the crop spacing (Table 1). Manual hand-weeding was conducted three times, the first before planting, the second, approximately two weeks after planting, and the third, three weeks after the second weeding. Data collected included:

1) Plant vigor: The plant vigor score was measured at two and four weeks after planting using a 1-4 rating scale (score): 1 = Low, 2 = Moderate, 3 = Vigorous, and $4=$ Highly Vigorous.

2) Stand count: Number of plants per four central rows, two weeks after planting.

3) For sorghum: Plant height (average of five random plants, pre-harvesting), panicle length (cm), weight of straw, grain yield, and 1000 seed weight.

4) For groundnut: Number of pods per plant, shelling percentage, hay yield, pod yield, and 100 seed weight.

5) For sesame: Plant height, number of capsules per plant, hay yield, seed yield, and 1000 seed weight. 
6) For cowpea: Pods per plant, seeds per pod, pod yield, hay yield, seed yield and 100 seed weight.

Table 1. Calculated fertilizer quantity in $\mathrm{kg} \cdot \mathrm{ha}^{-1}$ corresponding to fertilizer micro-dose level per planting hole.

\begin{tabular}{|c|c|c|c|c|c|}
\hline \multirow{3}{*}{ Crop } & \multirow{3}{*}{ Spacing (cm) } & \multicolumn{4}{|c|}{ Micro dose (g/hole) } \\
\hline & & 0 & 0.3 & 0.6 & 0.9 \\
\hline & & \multicolumn{4}{|c|}{ Equivalent dose (kg/ha) } \\
\hline Sorghum & $60 \times 40$ & 0 & 12.5 & 25.0 & 37.5 \\
\hline Groundnut & $60 \times 20$ & 0 & 25.0 & 50.0 & 75.0 \\
\hline Sesame & $60 \times 40$ & 0 & 12.5 & 25.0 & 37.5 \\
\hline Cowpea & $60 \times 30$ & 0 & 16.7 & 33.4 & 50.1 \\
\hline
\end{tabular}

On-farm trials were also conducted to study the effect of priming and micro-dosing. Each of the 15 selected farmers (men and women) was provided with $3 \mathrm{~kg}$ of 15-15-15 NPK fertilizer. The treatments in each field of the selected farmers consisted of:

1. Control

2. Seed priming

3. Seed priming + micro-dosing $(0.3 \mathrm{~g} /$ planting hole $)$.

Plot size for each treatment in the on-farm experiment was $360 \mathrm{~m}^{2}(15 \times 24 \mathrm{~m})$ with all cultural practices carried out by the farmers according to their preferences. Yields obtained from farmers' plots were analyzed according to the randomized complete block design, considering each farmer as a replicate [11]. The combined analysis was carried out over two seasons and means were separated using Duncan Multiple Range Test (DMRT) at levels of 0.01 and 0.05 [12]. The partial budgeting technique was used to assess and compare the economic returns and net benefits of the different treatments [13]. The average yield over seasons and replications in each treatment were used. The average field prices of the crops during 2011/2012 were taken from the markets in which the farmers sell their produce. Production cost, or the sum of all of the variable costs including labor and inputs costs (without fertilizer), was taken from the surveys, which were conducted annually by the Ministry of Agriculture, South Kordofan State, Sudan. In the micro-fertilizer treatment, the fertilizer cost was added based on the amount of fertilizer applied (Table 1. The fertilizer use efficiency (FUE) was computed according to the formula:

$$
\mathrm{FUEt}=(\mathrm{Yt}-\mathrm{Ct}) / \mathrm{Ft}
$$

where FUE is the fertilizer use efficiency for the treatment level, Yt is the grain yield for the treatment level, $\mathrm{Ct}$ is the grain yield from the control, and $\mathrm{Ft}$ is the fertilizer rate used in $\mathrm{kg} \cdot \mathrm{ha}^{-1}$ for the treatment level.

The value cost ratio was calculated as:

$$
\mathrm{VCRt}=(\mathrm{Yt}-\mathrm{Yc}) \times \mathrm{PGt} / \mathrm{CFt}
$$

where VCRt denotes the value cost ratio for the treatment level, Yt - Yc denotes the incremental grain yield resulting from fertilizer use in the treatment and the control, respectively, PGt denotes the grain price per $\mathrm{kg}$ and $\mathrm{CFt}$ denotes the cost of fertilizer per hectare of the treatment level. 
The total production cost including labor and input costs, was calculated by adding the fertilizer cost for each treatment to the production cost for each crop. The production cost for sorghum, groundnut, sesame, and cowpea was 353, 428, 283 and 179 SDG/ha, respectively. The production costs data were obtained from North Kordofan State Ministry of Agriculture 2010-2011 annual survey reports. The prices in $\mathrm{kg} \mathrm{ha}^{-1}$ of sorghum, groundnut, sesame, and cowpea, according to ElObeid Auction Market 2010-2011, were 1.25, 4.7, 2.83 and 3 SDG, respectively. Hay prices from the local market were $0.41,1.6,0.2$ and 1.0 SDG for the above crop order, respectively. The market price of 15-15-15 NPK fertilizer was 200 SDG per $50 \mathrm{~kg}$ sack (4 SDG/Kg).

\section{Results}

\subsection{Sorghum}

Results of the combined analysis over the two seasons (2009/2010 and 2010/2011) are shown in Table 2. Differences in stand count (plant population), plant vigor score (two and four weeks after planting), and plant height were highly and significantly affected by seed priming and micro-dose of mineral fertilizer $(p=0.01)$. Seed priming increased plant vigor, plant stand and plant height by $28 \%$, $14 \%$, and $3 \%$, respectively $(p<0.05)$, when compared to the control.

Table 2. Effect of seed priming and fertilizer micro-dosing on some traits of sorghum (combined across two seasons).

\begin{tabular}{|c|c|c|c|c|c|c|c|}
\hline Treatments & $\begin{array}{c}\text { Plant } \\
\text { pop./ha }\end{array}$ & $\begin{array}{c}\text { Vigor score } 2 \\
\text { WAP } \\
\end{array}$ & $\begin{array}{c}\text { Vigor score } 4 \\
\text { WAP }\end{array}$ & $\begin{array}{c}\text { Plant height } \\
\text { (cm) }\end{array}$ & $\begin{array}{c}\text { No. of } \\
\text { heads/plot }\end{array}$ & $\begin{array}{c}\text { No. of } \\
\text { seeds/head }\end{array}$ & $\begin{array}{c}1000 \text { seed } \\
\text { weight (gram) }\end{array}$ \\
\hline \multicolumn{8}{|c|}{ Seed Priming } \\
\hline Non-primed & 67842 & 2.16 & 2.88 & 179 & 97 & 751 & 40.9 \\
\hline Primed & 78446 & 3.00 & 3.35 & 185 & 113 & 930 & 42.7 \\
\hline $\mathrm{SE} \pm$ & $2260 * *$ & $0.21 * *$ & $0.17 * *$ & $3.0 * *$ & $4.6 * *$ & $33 * *$ & $0.54 * *$ \\
\hline \multicolumn{8}{|c|}{ Fertilizing micro-dosing (gram/planting hole) } \\
\hline Control & 69252 & 2.19 & 2.94 & 175 & 97 & 699 & 41.2 \\
\hline $0.3 \mathrm{~g} / \mathrm{hole}$ & 68261 & 2.44 & 3.13 & 178 & 96 & 739 & 40.5 \\
\hline $0.6 \mathrm{~g} / \mathrm{hole}$ & 75572 & 2.75 & 3.25 & 186 & 110 & 791 & 42.1 \\
\hline $0.9 \mathrm{~g} / \mathrm{hole}$ & 79492 & 2.94 & 3.50 & 190 & 117 & 1134 & 42.5 \\
\hline $\mathrm{SE} \pm$ & $1598 * *$ & $0.15 * *$ & $0.12 *$ & $2.1 * *$ & $3.2 * *$ & $47 * *$ & $0.38 * *$ \\
\hline C.V\% & 8.74 & 23.11 & 14.77 & 4.60 & 12.30 & 15.66 & 3.68 \\
\hline
\end{tabular}

$\mathrm{Ns}=$ not significant $*$ significant at $p \leq 0.05 ; * *$ significant at $p \leq 0.01$, WAP $=$ weeks after planting.

Plant stand, plant vigor score, and plant height also increased with micro-dosing. The highest increments were recorded for the application of $0.9 \mathrm{~g}$ of fertilizer, which increased plant stand, plant vigor, and plant height by $13 \%, 25 \%$, and $8 \%$, respectively. A similar effect of seed priming and micro-dosing $(p<0.01)$ was also observed in heads per plot, and 1000 seed weight. Number of heads per plot increased due to seed priming and micro-dosing by $30 \%$ and $16 \%$ respectively and number of seeds per head by $24 \%$ and $27 \%$, respectively $(p<0.01)$. Seed weight (g/1000 seeds) was significantly improved by seed priming and fertilization $(p<0.01)$. 
The yield differences in sorghum were significantly $(p<0.01)$ affected by seed priming and micro-dosing (Table 3). Seed priming increased average grain yield from $619 \mathrm{~kg} / \mathrm{ha}$ to $949 \mathrm{~kg} / \mathrm{ha}$. Compared to the control, micro-dosing of $0.3,0.6$, and $0.9 \mathrm{~g} /$ hole fertilizer increased grain yield by $12 \%, 42 \%$, and $84 \%$, respectively. Yield increased from $512 \mathrm{~kg} / \mathrm{ha}$ in the control treatment to $1371 \mathrm{~kg} / \mathrm{ha}$ in the "seed priming and $0.9 \mathrm{~g}$ fertilizer/pocket" treatment. This corresponds to a $167 \%$ yield increase. Seed priming and micro-fertilization also significantly increased straw yield by $21 \%$ and $23 \%$, respectively (Table 3). The highest straw yield of $7700 \mathrm{~kg} / \mathrm{ha}$ was recorded at the dose $0.9 \mathrm{~g} / \mathrm{hole}$, while the lowest straw yield of $4750 \mathrm{~kg} / \mathrm{ha}$ was obtained from the control, without seed priming or fertilization. The interaction between priming and micro-fertilization was only significant for plant height.

Table 3. Effect of seed priming and fertilizer micro-dosing on sorghum grain and straw yields ( $\mathrm{kg} / \mathrm{ha})$ combined across two seasons.

\begin{tabular}{|c|c|c|c|c|c|c|c|c|}
\hline \multirow{2}{*}{$\begin{array}{l}\text { Fertilizer } \\
\text { dose/hole }\end{array}$} & \multicolumn{4}{|c|}{ Grain yield (kg/ha) } & \multicolumn{4}{|c|}{ Straw yield (kg/ha) } \\
\hline & Non-primed & Primed & Mean & $\mathrm{SE} \pm$ & Non-primed & Primed & Mean & $\mathrm{SE} \pm$ \\
\hline $0.0 \mathrm{~g}$ & $512^{\mathrm{g}}$ & $652^{f}$ & 582 & \multirow{4}{*}{$104 * *$} & $4752^{\mathrm{h}}$ & $5251^{\mathrm{f}}$ & 5002 & \multirow{4}{*}{$323 * *$} \\
\hline $0.3 \mathrm{~g}$ & $500^{g}$ & $799^{\mathrm{c}}$ & 650 & & $4822^{g}$ & $5513^{d}$ & 5168 & \\
\hline $0.6 \mathrm{~g}$ & $688^{e}$ & $974^{\mathrm{b}}$ & 831 & & $5485^{\mathrm{e}}$ & $7200^{b}$ & 6342 & \\
\hline $0.9 \mathrm{~g}$ & $776^{d}$ & $1371^{\mathrm{a}}$ & 1074 & & $6164^{c}$ & $7701^{a}$ & 6932 & \\
\hline $\mathrm{SE} \pm$ & \multicolumn{3}{|c|}{$73 * *$} & \multicolumn{5}{|c|}{$228 * *$} \\
\hline
\end{tabular}

$\mathrm{Ns}=$ not significant; $*$ significant at $p \leq 0.05 ; * *$ significant $p \leq 0.01$. Different letters signify statistically different.

\subsection{Groundnut}

Seed priming and micro-fertilization positively affected crop establishment in groundnut by increasing plant population and vigor score $(p<0.01$, Table 4). Seed priming affected crop establishment in groundnut by increasing stand count by $16 \%$, plant vigor score two weeks after planting by $25 \%$ and plant vigor score four weeks after planting by $15 \%$. The number of pods per plant was not significantly affected by seed priming, but was by fertilization. Shelling out-turn and 100 seed weight were not significantly affected by neither seed priming nor fertilizer application $(p<0.05)$. Micro-fertilization significantly improved stand count (plant population) and vigor score from $4 \%$ to $24 \%$ and from $3 \%$ to $34 \%$, respectively. The plant characteristics were improved with increased levels of fertilizer. 
Table 4. Effect of seed priming and micro-dosing on some traits of groundnut (combined across two seasons).

\begin{tabular}{ccccccc}
\hline Treatments & Plant pop./ha & Vigor 2 WAP & Vigor 4 WAP & Shelling\% & No. of pods/plant & 100 seed wt. \\
\hline \multicolumn{7}{c}{ Seed priming } \\
\hline Non-primed & 102475 & 2.34 & 3.06 & 67.1 & 42.0 & 31.8 \\
Primed & 118984 & 2.94 & 3.59 & 66.8 & 42.8 & 32.2 \\
$\mathrm{SE} \pm$ & $7288.1 * *$ & $0.21 * *$ & $0.17 * *$ & $0.98 \mathrm{~ns}$ & $0.74 \mathrm{~ns}$ & $0.57 \mathrm{~ns}$ \\
\hline \multicolumn{7}{c}{ Fertilizer micro-dose (gram/planting hole) } \\
\hline Control & 96468 & 2.38 & 3.00 & 66 & 39 & 32.2 \\
$0.3 \mathrm{~g} /$ hole & 100340 & 2.44 & 3.38 & 67 & 41 & 31.9 \\
$0.6 \mathrm{~g} /$ hole & 126361 & 2.56 & 3.38 & 67 & 43 & 31.9 \\
$0.9 \mathrm{~g} /$ hole & 119750 & 3.19 & 3.56 & 67 & 47 & 32.3 \\
$\mathrm{SE} \pm$ & $5153.4 * *$ & $0.15 * *$ & $0.12 *$ & $0.70 \mathrm{~ns}$ & $1.05 * *$ & $0.41 \mathrm{~ns}$ \\
$\mathrm{C} . \mathrm{V} \%$ & 18.62 & 22.9 & 14.31 & 4.16 & 7.02 & 5.07 \\
\hline \multicolumn{7}{c}{ Ns = not significant; * significant at $p \leq 0.05 ; * *$ significant $p \leq 0.01$, WAP = weeks after planting. }
\end{tabular}

Seed priming and micro-fertilization significantly increased pod and hay yields $(p<0.01$, Table 5$)$. Seed priming increased average pod yield from 1995 to $2404 \mathrm{~kg} \cdot \mathrm{ha}^{-1}$, corresponding to a $20 \%$ yield increase, while micro-fertilization increased pod yield by $35 \%$ on average, from 1865 to $2629 \mathrm{~kg} \cdot \mathrm{ha}^{-1}$. Groundnut pod yield increased from $1716 \mathrm{~kg} \cdot \mathrm{ha}^{-1}$ in the control to $2955 \mathrm{~kg}$ in the treatment "priming and $0.9 \mathrm{~g}$ fertilizer per pocket", equivalent to a $72 \%$ increase in yield. Hay yield was also significantly increased by seed priming and micro-fertilization $(p<0.01)$. The best hay yield of $2637 \mathrm{~kg} \cdot \mathrm{ha}^{-1}$ was obtained from a micro-dose of 0.9 gram fertilizer per hole. There was no significant interaction between priming and micro-fertilization for all traits, with the exception of shelling out-turn.

Table 5. Effect of seed priming and micro dosing on groundnut pod and hay yields $(\mathrm{kg} / \mathrm{ha})$ combined across two season.

\begin{tabular}{|c|c|c|c|c|c|c|c|c|}
\hline \multirow{2}{*}{$\begin{array}{l}\text { Fertilizer } \\
\text { dose/hole }\end{array}$} & \multicolumn{4}{|c|}{ Pod yield (kg/ha) } & \multicolumn{4}{|c|}{ Hay yield (kg/ha) } \\
\hline & Non-primed & Primed & Mean & $\mathrm{SE} \pm$ & Non-primed & Primed & Mean & $\mathbf{S E} \pm$ \\
\hline $0.0 \mathrm{~g}$ & $1716^{\mathrm{f}}$ & $2013^{d}$ & 1865 & \multirow{4}{*}{$95 * *$} & $1737^{\mathrm{h}}$ & $2170^{f}$ & 1954 & \multirow{4}{*}{$97 * *$} \\
\hline $0.3 \mathrm{~g}$ & $1931^{\mathrm{e}}$ & $2291^{c}$ & 2111 & & $1915^{\mathrm{g}}$ & $2270^{c}$ & 2092 & \\
\hline $0.6 \mathrm{~g}$ & $2030^{d}$ & $2354^{b}$ & 2193 & & $2076^{\mathrm{f}}$ & $2752^{b}$ & 2414 & \\
\hline $0.9 \mathrm{~g}$ & $2303^{c}$ & $2955^{a}$ & 2629 & & $2212^{d}$ & $3061^{\mathrm{a}}$ & 2637 & \\
\hline $\mathrm{SE} \pm$ & & $7 * *$ & & & & $9 * *$ & & \\
\hline
\end{tabular}

$\mathrm{Ns}=$ not significant; $*$ significant at $p \leq 0.05 ; * *$ significant $p \leq 0.01$. Different letters signify statistically different.

\subsection{Sesame}

Results showed a strong and significant $(p \leq 0.01)$ effect of seed priming and micro fertilizing on plant stand, which increased by $56 \%$ with priming and $25 \%$ with micro-dosing, compared to the control (Table 6). Seed priming increased vigor score by 57\% ( $p \leq 0.01)$, while there was no effect of micro-dosing on plant vigor score. Plant height increased by $3 \%$ and $8 \%$ due to seed priming and micro-dosing, respectively. The number of capsules per plant increased $(p<0.05)$ by $12 \%$ and $15 \%$ 
with priming and micro-dosing, respectively. Seed priming showed no significant effect on sesame 1000 seed weight, while micro-dosing significantly increased 1000 seed weight by $8 \%(p=0.05)$.

Sesame seed yield was significantly increased by priming and micro-dosing $(p<0.01)$. Seed yield increased from 276 to $383 \mathrm{~kg} \cdot \mathrm{ha}^{-1}$ with priming and from 276 to $393 \mathrm{~kg} / \mathrm{ha}$ with micro-fertilizer application (Table 7). Seed priming and micro fertilization improved sesame hay yield by $55 \%$ and $24 \%$, respectively. The best seed and hay yields of 524 and $1942 \mathrm{~kg} \cdot \mathrm{ha}^{-1}$, respectively, were obtained from the combination of seed priming and micro-dosing of $0.9 \mathrm{~g}$ per pocket. Significant interaction between priming and micro-fertilization was observed for plant height, 1000 seed weight, and seed yield $(p<0.05)$. Although the highest seed yield was recorded for a $0.9 \mathrm{~g}$ micro-dose in combination with seed priming, the difference between $0.3 \mathrm{~g}$ and $0.9 \mathrm{~g}$ micro-dosing rates in combination with seed priming was not significant for seed yield.

Table 6. Effect of seed priming and micro-dosing of fertilizers on sesame combined across two seasons.

\begin{tabular}{cccccc}
\hline Treatments & Plant pop./ha & Vigour 2 WAP & Plant ht. (cm) & Av. no. of caps/plant & 1000 seed wt. (gm) \\
\hline Non-primed & 166683 & 1.97 & Seed priming & \\
Primed & 259836 & 3.09 & 132.6 & 61.2 & 2.37 \\
SE \pm & $19264 * *$ & $0.22 * *$ & 137.3 & 68.6 & 2.41 \\
\hline \multicolumn{7}{c}{ Fertilizer micro-dose (gram/planting hole) } \\
\hline Control & 180199 & 2.31 & 129 & 58 ns \\
0.3 g/hole & 204993 & 2.56 & 135 & 63 & 2.26 \\
0.6 g/hole & 246007 & 2.50 & 138 & 70 & 2.43 \\
0.9 g/hole & 221838 & 2.75 & 139 & 68 & 2.43 \\
SE \pm & $13261 *$ & $0.15 \mathrm{~ns}$ & $2.3 *$ & $2.3 *$ & 2.44 \\
C.V\% & 25.55 & 24.48 & 6.88 & 14.15 & $0.03 *$ \\
\hline
\end{tabular}

Ns $=$ not significant; $*$ significant at $p \leq 0.05$; $* *$ significant $p \leq 0.01$, WAP $=$ weeks after planting. Polp./ha $=$ population $/$ ha, Plant ht $(\mathrm{cm})=$ plant hight in $\mathrm{cm}, 1000$ seed wt. $(\mathrm{gm})=$ weight of 1000 seeds in gram.

Table 7. Effect of seed priming and micro-dosing on sesame seed and hay yields $(\mathrm{kg} / \mathrm{ha})$, combined across two seasons.

\begin{tabular}{|c|c|c|c|c|c|c|c|c|}
\hline \multirow{2}{*}{$\begin{array}{l}\text { Fertilizer } \\
\text { Dose/hole }\end{array}$} & \multicolumn{4}{|c|}{ Seed yield (kg/ha) } & \multicolumn{4}{|c|}{ Hay yield (kg/ha) } \\
\hline & Non-primed & Primed & Mean & $\mathbf{S E} \pm$ & Non-primed & Primed & Mean & $\mathrm{SE} \pm$ \\
\hline $0.0 \mathrm{~g}$ & $276^{\mathrm{e}}$ & $383^{c}$ & 330 & & $935^{\mathrm{h}}$ & $1335^{\mathrm{d}}$ & 1135 & \\
\hline $0.3 \mathrm{~g}$ & $243^{f}$ & $507^{a}$ & 375 & & $970^{g}$ & $1801^{b}$ & 1385 & \\
\hline $0.6 \mathrm{~g}$ & $348^{d}$ & $467^{b}$ & 408 & $19 * *$ & $1058^{\mathrm{f}}$ & $1430^{c}$ & 1244 & $100 *$ \\
\hline $0.9 \mathrm{~g}$ & $393^{c}$ & $524^{\mathrm{a}}$ & 458 & & $1223^{\mathrm{e}}$ & $1942^{\mathrm{a}}$ & 1582 & \\
\hline \multicolumn{9}{|l|}{ Mean } \\
\hline $\mathrm{SE} \pm$ & \multicolumn{3}{|c|}{$13 * *$} & \multicolumn{5}{|c|}{$70 * *$} \\
\hline
\end{tabular}




\subsection{Cowpea}

Differences in plant stand (plant population) and 100 seed weight were highly affected by seed priming and micro-dose of mineral fertilizer $(p<0.01$, Table 8$)$. Seed priming improved plant stand by $23 \%$ compared to non-primed, while micro-dosing treatments increased plant stand (plant population) by up to $26 \%$. Seed priming improved vigor score by $32 \%$ compared to non-primed, while no significant differences were observed among micro-dosing treatments for vigor score $(p<0.05)$. Seed priming did not affect the number of pods per plant, while micro-dosing increased pods number from 11 to 13 per plant. The number of seeds per pod was not significantly affected by either seed priming or fertilizer application $(p<0.05)$. Hundred seed weight was significantly increased due to seed priming and fertilizer micro-dose application.

Cowpea seed yield was significantly $(p<0.05)$ increased by $11 \%, 38 \%$ and $16 \%$ compared to the control with a micro-dose application of $0.3,0.6$ and $0.9 \mathrm{~g}$, respectively, while seed yield increased by $36 \%$ with seed priming (Table 9$)$. Hay yield highly and significantly $(P=0.01)$ increased with priming ( $115 \%$ increase) and fertilization (51\% increase) compared to the control. There was no significant interaction between priming and micro fertilizing for grain and hay yields.

Table 8. Effect of seed priming and micro fertilizing on cowpea combined across two seasons.

\begin{tabular}{cccccc}
\hline Treatments & Plant pop. & $\begin{array}{c}\text { Vigour 2 } \\
\text { WAP }\end{array}$ & $\begin{array}{c}\text { No. pods/plant } \\
\text { So. seeds/pod }\end{array}$ & 100 seed wt. gram \\
\hline Non-primed & 37938 & 2.31 & 13 & 9.1 & 18.2 \\
Primed & 46656 & 3.06 & 13 & 9.0 & 18.4 \\
SE \pm & $3570 * *$ & $0.23 * *$ & $0.74 \mathrm{~ns}$ & $0.51 \mathrm{~ns}$ & $0.10^{*}$ \\
\hline \multicolumn{5}{c}{ Fertilizer micro-dose (gram/planting hole) } \\
\hline Control & 34438 & 2.44 & 11 & 9 & 18.1 \\
0.3 g/hole & 39813 & 2.56 & 14 & 9 & 18.2 \\
0.6 g/hole & 48563 & 2.69 & 13 & 9 & 18.4 \\
0.9 g/hole & 46375 & 3.06 & 13 & 9 & 18.4 \\
SE \pm & $2524 * *$ & $0.17 \mathrm{~ns}$ & $0.52 * *$ & $0.36 \mathrm{~ns}$ & $0.10 * *$ \\
C.V $\%$ & 23.87 & 24.86 & 16.36 & 16.02 & 1.19 \\
\hline
\end{tabular}

$\mathrm{Ns}=$ not significant; $*$ significant at $p \leq 0.05 ; * *$ significant $p \leq 0.01$, WAP $=$ weeks after planting. 100 seed wt. gram=weight of 100 grains. Different letters signify statistically different.

Table 9. Effect of seed priming and micro-dosing on cowpea seed and hay yields $(\mathrm{kg} / \mathrm{ha})$, combined across two seasons.

\begin{tabular}{|c|c|c|c|c|c|c|c|c|}
\hline \multirow{2}{*}{$\begin{array}{l}\text { Fertilizer } \\
\text { Dose/hole }\end{array}$} & \multicolumn{4}{|c|}{ Seed yield (kg/ha) } & \multicolumn{4}{|c|}{ Hay yield (kg/ha) } \\
\hline & Non-primed & Primed & Mean & $\mathbf{S E} \pm$ & Non-primed & Primed & Mean & $\mathrm{SE} \pm$ \\
\hline $0.0 \mathrm{~g}$ & $191^{\mathrm{e}}$ & $240^{\mathrm{c}}$ & 215 & & $219^{g}$ & $414^{d}$ & 316 & \\
\hline $0.3 \mathrm{~g}$ & $203^{\mathrm{de}}$ & $275^{b}$ & 239 & & $216^{\mathrm{g}}$ & $488^{c}$ & 352 & \\
\hline $0.6 \mathrm{~g}$ & $239^{\mathrm{c}}$ & $356^{\mathrm{a}}$ & 297 & $20 *$ & $283^{f}$ & $657^{\mathrm{b}}$ & 470 & $41 * *$ \\
\hline $0.9 \mathrm{~g}$ & $217^{\mathrm{d}}$ & $283^{\mathrm{b}}$ & 250 & & $395^{\mathrm{e}}$ & $831^{\mathrm{a}}$ & 613 & \\
\hline Mean & 212 & 288 & 250 & & 278 & 597 & 438 & \\
\hline $\mathrm{SE} \pm$ & \multicolumn{4}{|c|}{$14 \mathrm{~ns}$} & \multicolumn{3}{|c|}{29} & \\
\hline
\end{tabular}

Ns $=$ not significant; $*$ significant at $p \leq 0.05 ; * *$ significant $p \leq 0.01$. Different letters signify statistically different. 


\subsection{On-Farm Trials}

Priming alone and priming combined with fertilizer application significantly increased the yield of sorghum, groundnut, and cowpea over the control in the two seasons $(p=0.01)$, while in sesame the increase was only significant in one season (Table 10).

Table 10. On-farm evaluation of seed priming and fertilizer micro-dosing at three villages (15 farmers from each village) in South Kordofan.

\begin{tabular}{|c|c|c|c|c|}
\hline Treatment & Sorghum & Groundnut & Cowpea & Sesame \\
\hline \multicolumn{5}{|c|}{ 1st season: 2009/2010-(yield kg/ha) } \\
\hline Control & $686^{\mathrm{c}}$ & $586^{\mathrm{c}}$ & $128^{\mathrm{b}}$ & $272^{b}$ \\
\hline Primed seeds & $860^{\mathrm{b}}$ & $731^{\mathrm{b}}$ & $207^{\mathrm{a}}$ & - \\
\hline Primed + fertilizer (0.3 gram) & $1022^{\text {a }}$ & $906^{\mathrm{a}}$ & $233^{\mathrm{a}}$ & $405^{\mathrm{a}}$ \\
\hline \multicolumn{5}{|c|}{ 2nd season: 2010/2011-(yield kg/ha) } \\
\hline Control & $607^{\mathrm{c}}$ & $886^{\mathrm{b}}$ & $253^{\mathrm{b}}$ & 181 \\
\hline Primed seeds & $837^{\mathrm{b}}$ & $1237^{\mathrm{a}}$ & $353^{\mathrm{a}}$ & - \\
\hline Primed + fertilizer ( 0.3 gram $)$ & $986^{\mathrm{a}}$ & $1438^{\text {a }}$ & $415^{\mathrm{a}}$ & 198 \\
\hline \# of participating farmers & 15 & 15 & 15 & 15 \\
\hline \# of participating villages & 3 & 3 & 3 & 3 \\
\hline
\end{tabular}

\section{Economic Analysis}

An economic analysis was undertaken to assess economic performance of the different treatments (Table 11). Generally, the highest returns were obtained in all crops when both seed priming and micro-fertilization were used. Micro-dosing without seed priming, even at low doses, negatively affected gross margin in sorghum, sesame and cowpea.

Table 11. Economic analysis of the different seed priming and micro-dosing treatments.

\begin{tabular}{ccccc}
\hline \multirow{2}{*}{ Treatments } & \multicolumn{4}{c}{ Net return (SDG/ha) } \\
\cline { 2 - 5 } & Sorghum & Groundnut & Sesame & Cowpea \\
\hline Non priming no fertilizer (control) & $287 \mathrm{f}$ & $7637 \mathrm{~h}$ & $498 \mathrm{~g}$ & $394 \mathrm{e}$ \\
Non priming + 0.3 g per planting hole & $222 \mathrm{~g}$ & $8548 \mathrm{~g}$ & $355 \mathrm{~h}$ & $363 \mathrm{f}$ \\
Non priming + 0.6 g per planting hole & $596 \mathrm{c}$ & $8913 \mathrm{f}$ & $602 \mathrm{f}$ & $404 \mathrm{e}$ \\
Non priming + 0.9 g per planting hole & $407 \mathrm{e}$ & $10096 \mathrm{~d}$ & $719 \mathrm{e}$ & $272 \mathrm{~g}$ \\
Priming no fertilizer & $462 \mathrm{~d}$ & $9033 \mathrm{e}$ & $801 \mathrm{~d}$ & $541 \mathrm{c}$ \\
Priming + 0.3 g per planting hole & $765 \mathrm{~b}$ & $10240 \mathrm{c}$ & $1102 \mathrm{a}$ & $580 \mathrm{~b}$ \\
Priming + 0.6 g per planting hole & $467 \mathrm{~d}$ & $10436 \mathrm{~b}$ & $939 \mathrm{c}$ & $755 \mathrm{a}$ \\
Priming + 0.9 g per planting hole & $1211 \mathrm{a}$ & $13161 \mathrm{a}$ & $1050 \mathrm{~b}$ & $470 \mathrm{~d}$ \\
SE \pm & 112 & 591 & 95 & 53 \\
\hline
\end{tabular}

* 15-15-15 NPK fertilizer price is $200 \mathrm{SDG}$ per $50 \mathrm{~kg}$ sack (4 SDG/Kg); ** Note: sorghum, groundnut, sesame and cowpea production costs are 353, 428, 283 and 179 SDG, respectively [14]; *** Note: sorghum, groundnut, sesame and cowpea price according to Obeid Auction Market, 2010-2011, are 1.25, 4.7, 2.83, and $3 \mathrm{SDG}$, respectively. Hay prices from the local market were $0.41,1.6,0.2$ and 1.0 for the above crop order, respectively. Different letters signify statistically different. 
Sorghum seed priming and application of $0.9 \mathrm{~g}$ fertilizer per hole increased the gross margin from 462 to $1211 \mathrm{SDG} / \mathrm{ha}$, while the treatment of non-priming with application of $0.9 \mathrm{~g}$ fertilizer per hole increased the net revenue from 278 to $407 \mathrm{SDG} / \mathrm{ha}$.

For groundnut, the net benefit increased from 9033 in the control to $13161 \mathrm{SDG} / \mathrm{ha}$ with the application of priming and $0.9 \mathrm{~g}$ fertilizer per hole. Priming with micro-dosing gave a higher return than non-priming with micro-dosing. However, unlike in other crops, groundnut yield increased with increasing micro-dosing rates up to $0.9 \mathrm{~kg}$ fertilizer per pocket. The revenue increase from micro-dosing and seed priming was much higher in groundnut compared to the other crops.

Sesame gross margin increased from $498 \mathrm{SDG} /$ ha in the control to 1102 in the treatment "priming combined with application of $0.3 \mathrm{~g}$ fertilizer per hole". Priming alone with micro dosing also gave a good return in sesame.

For cowpea, the gross margin increased from 541 in the control to 755 SDG/ha with the application of $0.6 \mathrm{~g}$ fertilizer per hole combined with seed priming. Fertilizer use efficiency (FUE) and value cost ratio (VCR) for grain yield and the total biological yield were the highest at the treatment combinations with the highest yields for all crops (Tables 12 and 13). FUE and VCR were always the highest in treatments which combined micro-dosing with seed priming, and were higher in sorghum and groundnut compared to sesame and cowpea. Adding the hay value to the grain value increased the FUE and VCR. It is worth mentioning that hay yield is a valuable agricultural bi-product which is utilized for animal feed in the dry months of the year. Sorghum straw is also utilized as building material in rural areas.

Table 12. Value cost ratio (VCR) of NPK fertilizer micro-dose rates with and without seed priming (VCR1-grain yield, VCR2-grain + hay yield). a $=$ non-primed seed, $\mathrm{b}=$ primed seeds.

\begin{tabular}{|c|c|c|c|c|c|c|c|c|}
\hline \multirow{2}{*}{$\begin{array}{l}\text { NPK rates } \\
\text { gram/hole }\end{array}$} & \multicolumn{2}{|c|}{ Sorghum } & \multicolumn{2}{|c|}{ Groundnut } & \multicolumn{2}{|c|}{ Sesame } & \multicolumn{2}{|c|}{ Cowpea } \\
\hline & VCR1 & VRC2 & VCR1 & VCR2 & VCR1 & VCR2 & VCR1 & VCR2 \\
\hline $0.3^{\mathrm{a}}$ & -0.3 & 0.27 & 10.11 & 12.96 & -1.70 & -1.56 & 0.54 & 0.41 \\
\hline $0.6^{\mathrm{a}}$ & 2.2 & 5.21 & 7.38 & 10.09 & 2.04 & 2.29 & 1.08 & 2.44 \\
\hline $0.9^{\mathrm{a}}$ & 2.2 & 6-06 & 9.20 & 11.70 & 2.21 & 2.69 & 0.39 & 3.02 \\
\hline $0.3^{\mathrm{b}}$ & 3.68 & 5.78 & 13.07 & 14.67 & 7.02 & 8.02 & 1.57 & 2.68 \\
\hline $0.6^{\mathrm{b}}$ & 4.03 & 11.83 & 8.01 & 19.65 & 2.38 & 2.60 & 2.60 & 4.42 \\
\hline $0.9^{\mathrm{b}}$ & 5.99 & 12.52 & 14.76 & 26.64 & 2.66 & 3.26 & 0.64 & 2.72 \\
\hline
\end{tabular}

Table 13. Fertilizer use efficiency (FUE $\mathrm{kg} \cdot \mathrm{kg}^{-1}$ ) of NPK fertilizer micro-dose rates with and without seed priming (FUE1-grain yield, FUE2-grain + hay yield). a = non-primed seed, $\mathrm{b}=$ primed seeds.

\begin{tabular}{|c|c|c|c|c|c|c|c|c|}
\hline \multirow{2}{*}{$\begin{array}{l}\text { NPK rates } \\
\text { gram/hole }\end{array}$} & \multicolumn{2}{|c|}{ Sorghum } & \multicolumn{2}{|c|}{ Groundnut } & \multicolumn{2}{|c|}{ Sesame } & \multicolumn{2}{|c|}{ Cowpea } \\
\hline & FUE1 & FUE2 & FUE1 & FUE2 & FUE1 & FUE2 & FUE1 & FUE2 \\
\hline $0.3^{\mathrm{a}}$ & -0.96 & 4.64 & 8.60 & 22.84 & -2.64 & 0.16 & 0.72 & 0.54 \\
\hline $0.6^{\mathrm{a}}$ & 7.04 & 36.36 & 6.28 & 13.06 & 2.88 & 7.80 & 1.44 & 3.36 \\
\hline $0.9^{\mathrm{a}}$ & 7.04 & 44.69 & 7.83 & 14.16 & 3.12 & 10.80 & 0.52 & 4.03 \\
\hline $0.3^{\mathrm{b}}$ & 11.76 & 32.72 & 11.12 & 15.12 & 09.92 & 29.92 & 2.10 & 06.53 \\
\hline $0.6^{\mathrm{b}}$ & 12.88 & 90.84 & 06.82 & 18.46 & 03.36 & 7.72 & 3.47 & 10.75 \\
\hline $0.9^{\mathrm{b}}$ & 19.17 & 84.50 & 12.56 & 24.44 & 3.76 & 15.68 & 0.86 & 09.18 \\
\hline
\end{tabular}


The economic analysis of the on-farm experiment confirmed the positive impact of seed priming and micro-dosing (Table 14). There was an increase for all crops, with the highest increase observed in groundnut. The increase in gross margin from the control to the treatment combining seed priming and micro-dosing was 2178, 444, 372, and 469 for groundnut, sorghum, cowpea, and sesame, respectively.

Table 14. The effect of seed priming and micro-dosing on gross margin in on-farm farmer managed plots.

\begin{tabular}{ccccc}
\hline \multirow{2}{*}{ Treatment } & \multicolumn{4}{c}{ Combined (30 farmers) } \\
\cline { 2 - 5 } & Groundnut & Sorghum & cowpea & Sesame \\
\hline Control & 3265 & 513 & 387 & 13 \\
Priming & 4662 & 824 & 690 & \\
P + M & 5443 & 957 & 759 & 482 \\
SE & $283 * *$ & $40 * *$ & $54 * *$ & $74 * *$ \\
CV & 35 & 28 & 48 & 163 \\
\hline
\end{tabular}

Ns $=$ not significant; $* *$ significant $p \leq 0.01$.

\section{Discussion}

Seed priming and micro-dosing represent low-cost approaches to increase yields of small-holders under marginal dry land conditions [5,8,9].

Seed priming is a simple strategy to improve plant establishment and alleviate the negative effects associated with stress exposure. Seed priming has been shown to reduce germination time, improve plant stand, increase vigor, shorten the growing cycle, and increase crop yield $[5,7,8,15]$. It is a technology that is particularly suited to adverse environmental conditions. The results of the present study have shown that seed priming significantly improved crop establishment and seedling vigor of rain-fed sorghum, groundnut, sesame, and cowpea grown on clay soil in South Kordofan State. This is important as seed priming and micro-dosing can reduce the need for re-sowing. Similar results were obtained with these crops under rain-fed condition on sandy soils in North Kordofan State [10].

Previous studies have shown that seed priming and micro-dosing can increase yield at a low cost $[2-5,9,10,16]$. Micro-dosing was also reported to improve the fertilizer use efficiency compared to broadcasting of fertilizer [17]. The results from this study indicate that seed priming combined with micro-dosing is not only an approach for sandy soils, but also works well on the cracking clay soil of South Kordofan State. Most previous studies on micro-dosing have been with cereal crops, but this study shows that micro-dosing and seed priming is also an appropriate technology in groundnut, sesame, and cowpea. The yield increase observed for the best treatment compared to the control was $85 \%, 41 \%, 84 \%$ and $48 \%$ in sorghum, groundnut, sesame, and cowpea, respectively. The best treatment with regard to net return in sorghum and groundnut was found to be seed priming in combination with $0.9 \mathrm{~g}$ of NPK fertilizer, while $0.3 \mathrm{~g}$ and $0.6 \mathrm{~g}$ in combination with priming were the doses with highest net returns in sesame and cowpea, respectively. These combinations were significantly better than all other combinations including the control. Higher micro-dose response was found in groundnut in the clay soils of South Kordofan State compared to the sandy soils of North Kordofan State [10]. The highest fertilizer use efficiency (FUE) and value cost ratio (VCR) corresponded with the combination which gave the highest total grain and biological yield, except for 
sorghum. The results of this study show that the agronomic and economic benefits of micro-dosing can be increased if it is combined with seed priming, as the VCR were generally higher when seed priming was combined with micro-dosing, compared to when micro-dosing was used alone. Seed priming therefore makes micro-dosing a safer investment. The on-farm study confirms that seed priming and micro-dosing can greatly increase gross margin. This study shows that the type of crop onto which the fertilizer is applied is of importance. If the objective is to have the highest possible economic return, it is far better to apply the fertilizer in groundnut as the VCR for the best treatment in groundnut was 26.6, whereas the best VCR for sorghum, sesame, and cowpea were 12.5, 8.0, and 4.4, respectively. This illustrates that applying micro-dosing combined with seed priming is a very safe investment as the VCR should be above 2 and preferably above 4 under dry land conditions where the risk is high [18]. This point can also be illustrated by looking at the increase in gross return from the control to the best treatment. For groundnut, this increase was $5524 \mathrm{SDG} /$ ha whereas it was 924, 607, and 285 for sorghum, sesame, and cowpea, respectively. The on-farm experiments also confirmed that the highest return is found in groundnut. The main reason the return on fertilizer is higher in groundnut compared to other crops is the high price of this crop compared to the other crops.

\section{Conclusions}

This study showed that it is possible to increase the productivity of sorghum, sesame, groundnut, and cowpea in the semi-arid cracking clay of South Kordofan State at a low cost and at a very moderate risk for farmers through seed priming and fertilizer micro-dose application. Seed priming with micro-doses of $0.9 \mathrm{~g}$ improved crop establishment and seedling vigor of sorghum and groundnut, while the combination of seed priming and $0.3 \mathrm{~g}$ micro-fertilization improved crop establishment, seedling vigor and grain yield in sesame. Seed priming and micro-fertilization of $0.6 \mathrm{~g}$ improved crop establishment and grain yield in cowpea. The highest economic return, FUE, and VCR corresponded to the treatment which produced the highest grain and total biological yield in each crop. Seed priming and micro-dosing can be considered as a safe option for farmers, particularly if used in groundnut and sorghum.

\section{Acknowledgments}

Sincere thanks are due to the Sudan and Norway Drylands Coordination Group (DCG) for their assistance and support that made this work possible. Our thanks are also extended to the Dry Lands Research Center (ARC) and ADRA (Sudan) for their cooperation and facilitation. Thanks are due to Mutaz M. Elsadig, Sudan, DCG coordinator, for his keen follow up and for facilitating the implementation of the project. Special thanks to Edaw Mohamed Idris, technician at El-Obeid Research Station, for his help in trial conduction and data collection. Sincere thanks are also extended to Khalid Ali Issa and Faiz Ali Ahmed, the drivers who made the journeys to and from trial sites easy and enjoyable. We are very grateful to the members of the communities who participated in the implementation of the activities. 


\section{Author Contributions}

The authors contributed to the design, implementation, analyzing and write-up of the paper.

\section{Conflicts of Interest}

The authors declare no conflict of interest.

\section{References}

1. Osman, A.K.; Ali, M.K. Crop production under traditional rain-fed agriculture. In Proceedings of the National Symposium on: Sustainable Rain-Fed Agriculture, Khartoum, Sudan, 17-18 November 2009; pp. 113-131.

2. Hayashi, K.; Abdoulaye, T.; Gerard, B.; Bationo, A. Evaluation of application timing in fertilizer micro-dosing technology on millet production in Niger, West Africa. Nutr. Cycl. Agroecosyst. 2008, 80, 257-265.

3. Klaij, M.C.; Genard, C.; Reddy, K.C. Low input technology options for millet based cropping systems in the Sahel. Exp. Agric. 1994, 30, 77-82.

4. Aune, J.; Doumbia, M.; Berthe, A. Microfertilization sorghum and pearl millet in Mali. Outlook Agric. 2007, 36, 199-203.

5. Aune, J.; Bationo, A. Agricultural intensification in the Sahel: The Ladder Approach. Agric. Syst. 2008, 98, 119-125.

6. Aune, J.B.; Ousman, A. Effect of seed priming and micro dosing of fertilizer on sorghum and pearl millet in western Sudan. Exp. Agric. 2011, 47, 419-430.

7. Harris, D.; Pathan, A.K.; Gothkar, P.; Joshi, A.; Chivasa, W.; Nyamudeza, P. On-farm seed priming: Using participatory methods to revive and refine a key technology. Agric. Syst. 2001, 69, 151-164.

8. Harris, D. Development and testing of "on-farm" seed priming. Adv. Agron. 2006, 90, 129-178.

9. Osman, A.K.; Abdalla, E.A.; Mekki, M.A.; Elhag, F.M.A.; Aune, J. Effect of seed priming and fertilizer micro dosing on Traditional Rain-Fed Crops of North Kordofan. In Proceedings of the 49th National Crop Husbandry Committee Meeting, Wad Medani, Sudan, 21 December 2010.

10. Osman, A.K.; Aune, J.B. Effect of seed priming and micro dosing of fertilizer on groundnut, sesame and cowpea in western Sudan. Exp. Agric. 2011, 47, 431-443.

11. Gomez, K.A.; Gomez, A.A. Statistical Procedures for Agricultural Research; Wiley: New York, NY, USA, 1984; p. 680.

12. MSTAT-C. User's Guide to MSTAT-C; MSTAT Development Team, Michigan State University: East Lansing, MI, USA, 1983.

13. CIMMYT. From Agronomic Data to Farmer Recommendations: An Economics Training Manual; CIMMYT: Batan, Mexico, 1998

14. MOA. Ministry of Agriculture, North Kordofan State, Department of Planning and Agricultural Statistics, Agricultural Season Evaluation Report; MOA: Auckland, New Zealand, 2011.

15. Ashraf, C.M.; Abu-Shakra, S. Wheat seed germination under low temperature and moisture stress. Agron. J. 1978, 70, 135-139. 
16. Buerkert, A.; Bationo, A.; Piepho, H.P. Efficient phosphorus application strategies for increased crop production in sub-Saharan West Africa. Field Crop. Res. 2001, 72, 1-15.

17. Tabo, R.; Bationo, A.; Hassane, O.; Amadou, B.; Fosu, M.; Sawadogo-Kabore, S.; Ndjeunga, J.; Fatondji, D.; Korodjouma, O.; Abdou, A.; et al. Fertilizer Micro Dosing for the Prosperity of the Resource Poor Farmers: A success story. In Proceedings of Increasing the Productivity and Sustainability of Rainfed Cropping Systems of Poor Smallholder Farmers, Tamale, Ghana, 22-25 September 2008.

18. Koning, N.; Heerink, N.; Kauffman, S. Integrated Soil Improvement and Agricultural Development in West Africa: Why Current Policy Approaches Fail; Wageningen Agricultural University: Wageningen, The Netherlands, 1998.

(C) 2015 by the authors; licensee MDPI, Basel, Switzerland. This article is an open access article distributed under the terms and conditions of the Creative Commons Attribution license (http://creativecommons.org/licenses/by/4.0/). 